Original Article

\title{
Habitat selection by Asiatic black bear (Ursus thibetanus) in Siran and Kaghan Valleys, Pakistan
}

\author{
Seleção de habitat pelo urso-negro asiático (Ursus thibetanus) nos vales Siran e \\ Kaghan, Paquistão
}

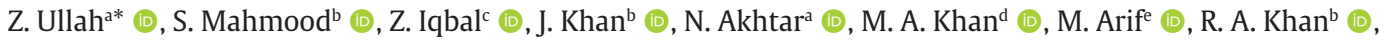

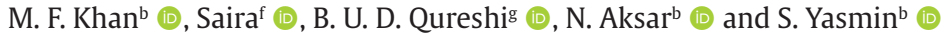

aHazara University Sub Campus Battagram, Department of Zoology, Khyber Pakhtunkhwa, Pakistan

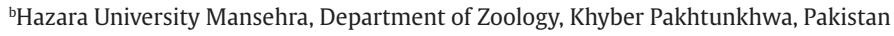

'Hazara University Mansehra, Department of Botany, Khyber Pakhtunkhwa, Pakistan

dSustainable Forest Management Project, Islamabad, Pakistan

eSustainable Forest Management Project, Peshawar, Khyber Pakhtunkhwa, Pakistan

fUniversity of Swabi, Department of Zoology, Khyber Pakhtunkhwa, Pakistan

${ }^{\mathrm{g}}$ Government Degree College Athmuqam, Azad Jammu and Kashmir, Pakistan

\begin{abstract}
Asiatic black bear is present in variety of habitats like broad-leaves and coniferous forests, extending form sea level to $4300 \mathrm{~m}$ elevation and change their habitat for food purpose seasonally. The present study was conducted at Kaghan and Siran Valleys, District Mansehra, Khyber Pakhtunkhwa, Pakistan to assess habitat of black bear. Line transect method was used for observation of bear signs. Twelve meter circular radius plots were selected for the concern vegetation's i.e. (trees, shrubs and herbs) and three to six plots were placed in each transect. At the result of sign survey, thirteen different categories of bear signs were recorded and encounter rate was calculated for each sign. A total of 1858 signs were observed during field surveys. Total (81\%) coniferous species were recoded among trees, with the highest appearance of Pinus wallichiana (34.22\%) and Spruce spp (27.76\%), similarly broad leaves trees $(18.56 \%)$ were also recoded from habitat plots. Most of the signs were encountered in bushy areas, whereas high number of Viburnum Spp (60.29\%) was present. It is indicated that black bear prefers blend of Coniferous Trees, Viburnum and Ferns Species; probably because these plants provide enough food, protection, and meticulous shelter because more than $80 \%$ of habitat composed of these three species. Currently habitat destruction and increase in human population are the up-growing issues for wild animals (especially Asiatic black bear), which is highly sensitive to such problems. High levels of conservation efforts are recommended for the protection of black bear habitat and to avoid human interference in their territory.
\end{abstract}

Keywords: habitat, Asiatic black bear, plants species, transect, Ursus thibetanus.

\begin{abstract}
Resumo
O urso-negro asiático está presente em uma variedade de habitats, como folhas largas e florestas de coníferas, estendendo-se do nível do mar até 4.300 m de altitude e mudando seu habitat para fins alimentares sazonalmente. O presente estudo foi conduzido nos vales Kaghan e Siran, distrito de Mansehra, Khyber Pakhtunkhwa, Paquistão, para avaliar o habitat do urso preto. O método de transecto linear foi usado para a observação de sinais do urso. Parcelas de raio circular de $12 \mathrm{~m}$ foram selecionadas para a vegetação de preocupação, ou seja, árvores, arbustos e ervas, e 3 a 6 parcelas foram colocadas em cada transecto. No resultado da pesquisa de sinais, 13 categorias diferentes de sinais de urso foram registradas e a taxa de encontro foi calculada para cada sinal. Um total de 1858 sinais foi observado durante os levantamentos de campo. 0 total (81\%) de espécies de coníferas foi recodificado entre as árvores, com maior aparecimento de Pinus wallichiana (34,22\%) e Spruce spp (27,76\%); árvores de folhas largas (18,56\%) também foram recodificadas em parcelas de habitat. A maioria dos sinais foi encontrada em áreas com arbustos, enquanto um alto número de Viburnum spp (60,29\%) estava presente. É indicado que o urso-negro prefere a mistura de árvores coníferas, espécies de viburnos e samambaias; provavelmente porque essas plantas fornecem alimento suficiente, proteção e abrigo meticuloso porque mais de $80 \%$ do habitat é composto por essas três espécies. Atualmente, a destruição do habitat e o aumento da população humana são questões crescentes para os animais selvagens, especialmente o urso-negro asiático, que é altamente sensível a esses problemas. Altos níveis de esforços de conservação são recomendados para a proteção do habitat do urso-negro e para evitar a interferência humana em seu território.
\end{abstract}

Palavras-chave: habitat, urso-negro asiático, espécies de plantas, transecto, Ursus thibetanus.

*e-mail: zaibullah_zoology@hu.edu.pk

Received: January 23, 2021 - Accepted: February 16, 2021

This is an Open Access article distributed under the terms of the Creative Commons Attribution License, which permits unrestricted use, distribution, and reproduction in any medium, provided the original work is properly cited. 


\section{Introduction}

Asiatic black bear (Ursus thibetanus G. [Baron] Cuvier, 1823 ) is considered one of the largest carnivore species in the world (Ripple et al., 2014). It is distributed through Pakistan, Afghanistan, Iran, India, Japan, Indo-China, Korea, Laos, Vietnam and Taiwan (McLellan and Reiner, 1994; Escobar et al., 2015; Garshelis and Steinmetz, 2016). In Pakistan, black bear habitat consists of moist temperate coniferous forest, dry temperate forest and tropical woodlands including Neelum, Kaghan, Siran valleys, Battagram and low elevated areas of Gilgit-Baltistan (GB), Pakistan (Schaller, 1977; Roberts, 1997; Woods and Kalpatrick, 1997; Garshelis and Steinmetz, 2016; Ullah et al., 2020).

Asiatic black bear occurs in variety of habitats including broad-leaved and coniferous forests, extending form sea level to the elevation of $4300 \mathrm{~m}$ (Garshelis and Steinmetz, 2016). They prefer shrubs and dense forest, occupying different habitats that include wetlands, meadows, planes and burn areas (Liley and Walker, 2015). The species is known to change its habitat for food purpose seasonally (Kumar and Viswanath, 2003; Garshelis and Steinmetz, 2016), seasonal migration of black bear depends upon their diet activity, denning positions, reproductive foraging, and breeding (Roger's). These movements follow well developed corridors like human trails, game trails, open creek beds, edges, shorelines, logging roads and sandbars or rivers (Stevens et al., 1988).

It is very interesting to study the feeding habits of black bear before and after the hibernation period (Howe et al., 2010; Mclellan, 2011; Garshelis and Steinmetz, 2016). Before the hibernation black bear try to take much food to increase their body weight, at least double. Shortage of ideal food can stop a female to produce cubs and no chances to cross harsh winter season (Howe et al., 2010; Myers, 2016). In spring season food provide nutrients to reconstruct muscle physique and maintenance of lactation in females (McLellan, 2011; Pires and Moreto, 2016). Generally, females occupy very clear home ranges between 12 to $50 \mathrm{~km}^{2}$ (Amstrup and Beecham, 1976; Young and Ruff, 1982). Sub-adult males live in very larger home ranges sometime more than $50 \mathrm{~km}^{2}$ depend upon availability of food sources and den selection (Howe et al., 2010). An adult male may occupy five times larger home range than that of mature female. Females and their descendant's individuals share home ranges with one another (Servheen, 1990; Myers, 2016). Differences in home ranges depend upon variability in habitat, availability of food like production and distribution of oaks and suitability of den sites (Hazumi, 1993). Maximum number of bear species ware declined due to habitat destruction, increased human activities, grazing of livestock in bear habitat (Servheen, 1990).

The current study aimed at assessing suitable habitat of Asiatic black bear in both valleys, population of different plant species such as trees, shrubs and herbs were determined on the bases of bear sign observations. This type of research point out potential sites, habitat strength, availability of food and shelter which promoted diversity and status of black bear.

\section{Materials and Methods}

\subsection{Study area}

The present study was conducted at Kaghan and Siran valleys located in north-east of District Mansehra, Khyber Pakhtunkhwa, Pakistan $\left(34.234^{\circ}\right.$ to $35.184^{\circ} \mathrm{N}$ and $72.817^{\circ}$ to $74.134^{\circ} \mathrm{E}$ ) (Ullah et al., 2020). Geographical location of both valleys is bordered with District Battagram, Azad Jammu and Kashmir (AJK) and Gilgit Baltistan (GB) (Figure 1). Kaghan valley is very important site for wildlife. It contains protected areas including national parks (Saif

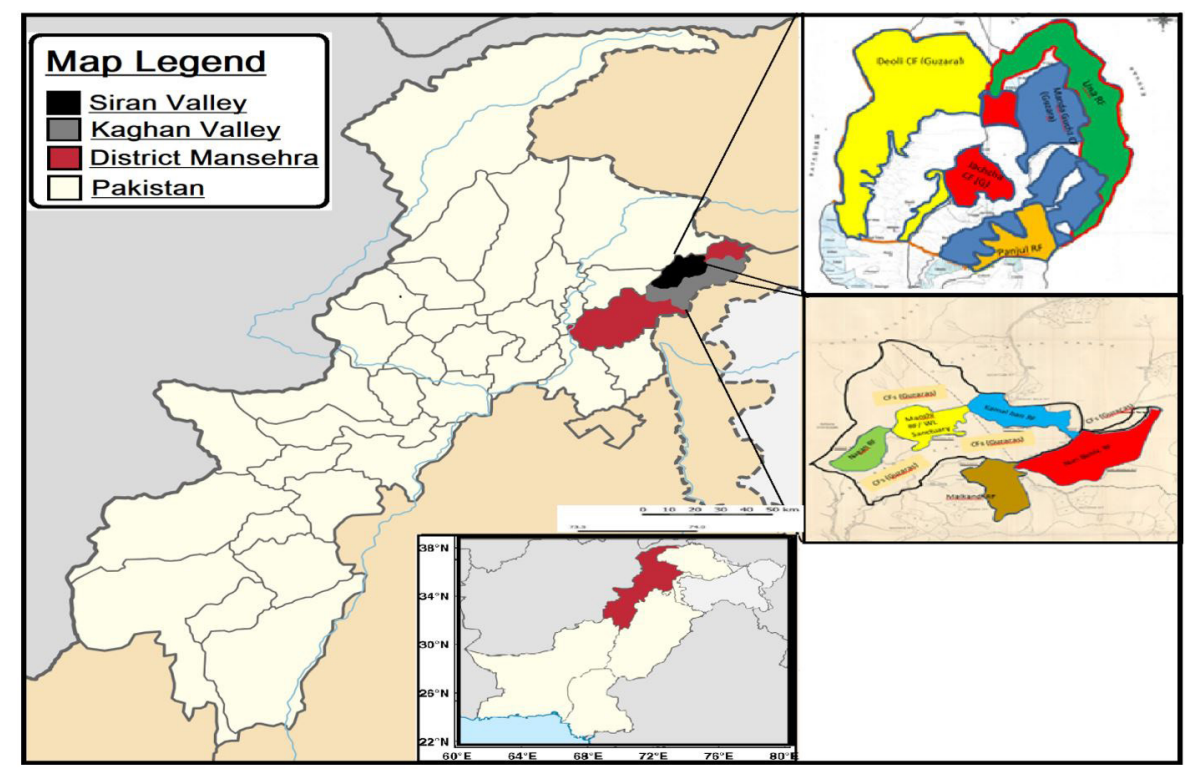

Figure 1. Map of the study area represent two valleys. 
Ul Malook and Lulusar-Dodipat) and a Wildlife Sanctuary (Manshi). Various animals and bird species are found in tourist spots (Shugran, Seri Paya, Nadi Bangla, Manshi Top and Sharran). Siran Valley located at the east of Kaghan valley is very famous spot for tourist hiking especially to elevated Mountain "Mossa Musalla" (4000m) (Ullah et al., 2020). Both valleys are composed of diverse ecosystems including moist temperate coniferous forest, sub-alpine forest and subtropical woodland.

\subsection{Methods}

Sign survey and transect methods were selected for collection of bear signs. Habitat plots were set up for recording important plants species and their numbers in each transect. A total of 33 long transects $(500 \mathrm{~m}$ long and $20 \mathrm{~m}$ width) were drawn in both valleys. Selection of the transect area was based on bear sign observations. Twelve (12) meter circular radius plots were selected for relevant vegetation study i.e. Trees, Shrubs and Herbs (Figure 2). Approximately three to six plots were made along each transect. Those sites were selected for plots set up where most of the bear signs were observed. Plots were set up by the help of three members of the survey team where two persons draw the radius length, and one person collected plant species and recorded their numbers for habitat assessment. The collected data was primarily recorded on data sheets and pictures. Number of plots selection was based on bear signs observed in different part of transect (Waseem and Ali, 2011).

\section{Results}

\subsection{Sign survey}

At the result of sign survey techniques, thirteen different categories of bear signs were recorded, these are: pug marks, claw marks, scat samples, bark off, plants uprooting, dig marks, stone replacing, place of livestock's killing, hair samples, crop damages, coarse wood damages, place of temporary setting and bees nest damaging. Each sign was recorded by taking the GPS reading and photography. Encounter rate was calculated for each sign from all transects. Encounter rate (ER) was calculated by following this equation, number of each sign divided by length of transect (No of sign/transect length) (Waseem and Ali, 2011; Khan et al., 2021; Rahat et al., 2020; Ullah et al., 2021; Ahmad et al., 2021).

Each sign was observed from different transects, these signs represent behavior of black bears. Total of 1858 bear signs were observed during field survey, among these the highest number of sign was dig marks (1213) observed.

\subsection{Habitat analysis}

Habitat analysis was carried out within each transect to collect all necessary information's about vegetation. Vegetation of study area was divided into three major categories; trees, shrubs and herbs. Among trees, generally two types were observed; coniferous trees and broad leave trees. Percentage of each plant species and their abundance were recoded from each transect (Table 1 and 2) for habitat assessment of the black bear.

\subsubsection{Trees}

Total (81\%) coniferous species were recoded from both valleys, among these the highest percentage is Pinus wallichiana (34.22\%), Spruce spp (27.76\%) and Fir spp (13.54\%). The remaining 5.48\% was Cedrus deodara, Chir pine and Taxus baccata. Some broad leaves species (18.56\%) were also recoded from habitat plots. Highest rate of broad laves trees was 4.56\% Himalayan horse chestnut (Aesculus indica), 4.18\% Parrotiopsis jacquemontiana, and 3.95\% Quercus spp while remaining $5.87 \%$ was Alanthus spp, Walnut spp,

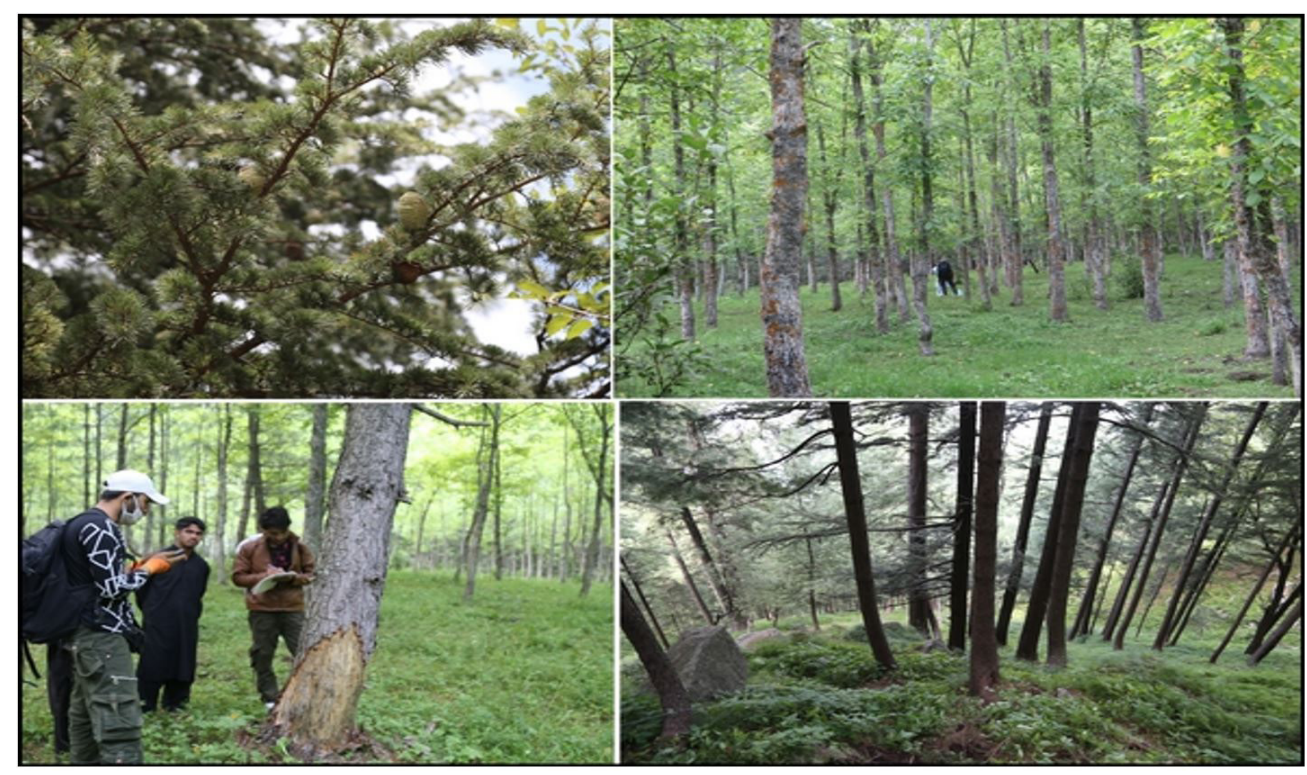

Figure 2. Habitat analysis during field survey. 


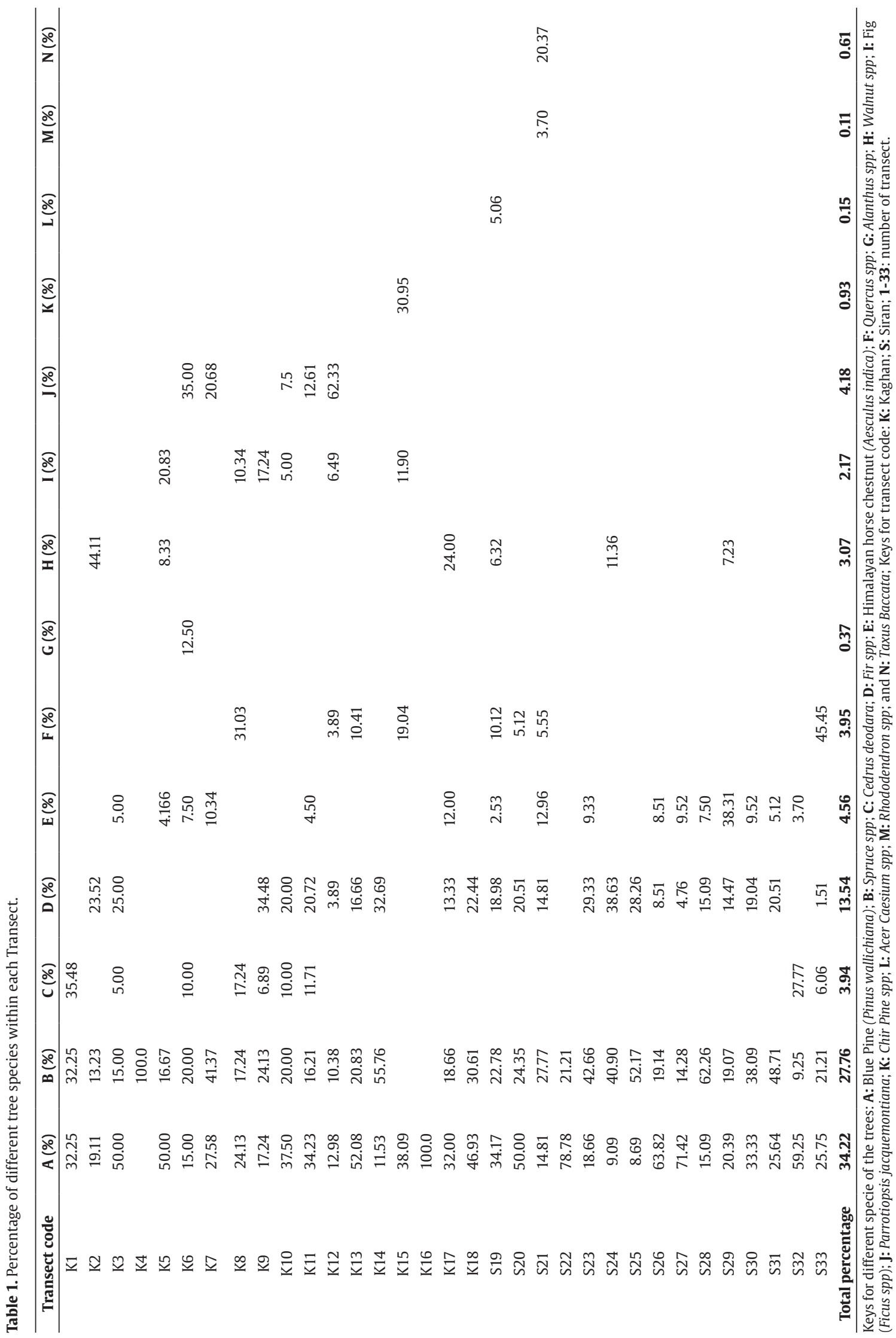




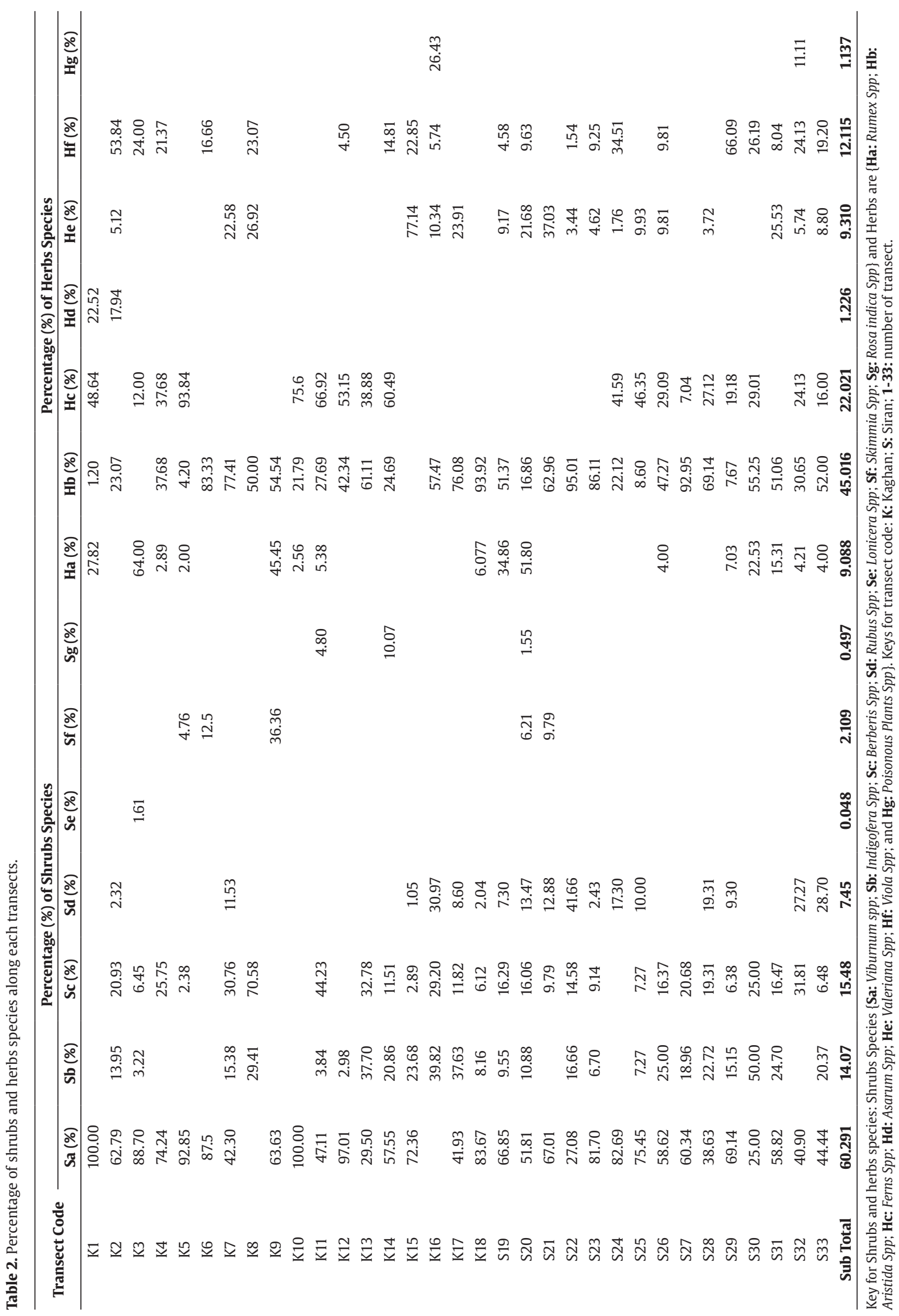




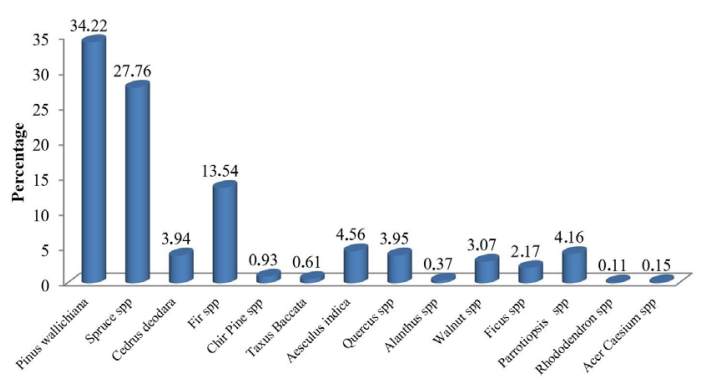

Figure 3. Percentage of tree species from both valleys.

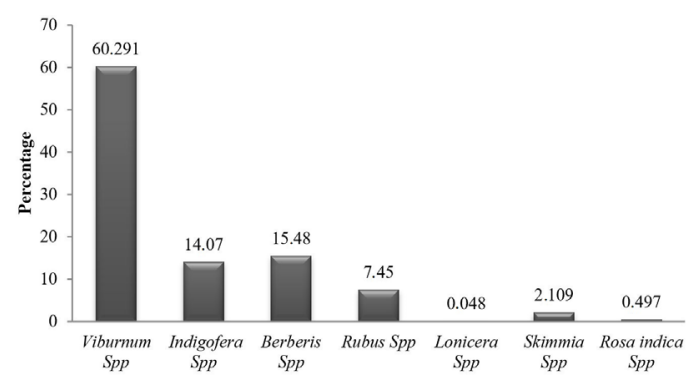

Figure 4. Percentage of shrub species from both valleys.

Fig (Ficus spp), Acer Caesium spp and Rhododendron spp (Figure 3).

\subsubsection{Shrubs}

According to analysis of this study, Viburnum Spp (60.29\%) was recorded with the highest number of shrub species from both valleys. Signs of the black bear were mostly found from shrubby area where high number of Viburnum Spp species found. Among 33 transects Viburnum Spp species was found from 31 transect. Barriers and leaves of Viburnum Spp are the best food of black bear. Study area represents the high number of Viburnum Spp among shrubs, and approximately $50 \%$ of habitat is composed of viburnum plants. Second and third highest number of shrub species recorded was Berberis Spp (15.48\%) and Indigofera Spp (14.07\%). Other shrubs species were also recorded from the study area, like Rubus spp, Lonicera Spp, Skimmia Spp, and Rosa indica Spp are 10.09\% (Figure 4).

\subsubsection{Herbs}

Habitat of black bear was also consisting of different herbs species. Herbs species evaluation is very difficult task during field survey because it required keen observation and careful data collection. Among herbs Aristida Spp was found (45.01\%), Ferns Spp (22.02\%) and Viola Spp (12.11\%). While remaining (20.75\%) herbs species were Rumex Spp, Asarum Spp, Valeriana Spp, and Poisonous Plants Spp.

Habitat analysis point out that black bear of Kaghan and Siran valleys are mostly found in combination with trees, shrubs and herbs. Mostly black bear prefers a blend of coniferous trees, viburnum shrubs and ferns species of herbs, because these plants species provide enough food, well protection, and meticulous shelter for black bear. More than $80 \%$ of habitat of black bear was composed of these three species (Conifers spp, Viburnum spp and Ferns spp).

\section{Discussion}

According to Waseem and Ali, 2011, black bear prefer to coniferous plants with support of broad leaves species, 86\% conifers were present in Malakandi reserve forest while remaining was broad leaves plant species. Similarly 90\% conifers were found in Punjul reserve forest. Other plants like cherry, viburnum and other species were also conformed as black bear food. Trees with large diameter provide excellent shelter for black bear. The present study revealed that habitat of Asiatic black bear consists of $81 \%$ conifers and $19 \%$ broad leaves in both valleys. Among all shrubs Viburnum spp was recorded with the highest percentage. During habitat analysis herbs species were also found, Aristida Spp and Ferns Spp were recorded the main herbs from both valleys.

Both studies were conducted in the same areas for habitat analysis of black bear. The upper mention study was conducted only in two forests (Malakandi and Punjul) of both valleys while our study was conducted in all forests ( 9 in Kaghan and 5 in Siran) of both valleys. On other hand this study was also focused on shrubs and herbs species which make $60 \%$ contribution of remarkable habitat and perfect shelter. It is determined that, this study represent updated and detailed information's about black bear habitat in district Mansehra.

\section{Conclusion}

It is concluded that black bear prefer those areas where conifers viburnum and herbs species are abundantly present as they provide food and shelter for bear population. Among both valleys we point out that Siran valley is the best habitat of black bear as compare to Kaghan because of dense vegetation and low rate of human interruption. Total (81\%) coniferous species/trees, (60.29\%) Viburnum Spp /shrubs and (45.01\%) Aristida Spp/herbs were recorded for habitat assessment of black bear in both valleys. More than $80 \%$ of habitat of the black bear is composed of the three major species (Conifers spp), (Viburnum spp) and (Ferns spp).

\section{Recommendations}

Very high levels of conservation effort are recommended for the protection of black bear habitat in District Mansehra. For this purpose we recommend that Kaghan and Siran valleys must be converted to a protected national park where wild animals can live freely without human interference.

\section{Acknowledgements}

The present study was carried out under the sustainable forest management project (SFM) in the said area. We are thankful to all members of SFM and wildlife staff 
of District Mansehra for providing opportunity for the conduction of research.

\section{References}

AHMAD, M., KHAN, R.A., ULLAH, Z., SAJID, M., KHAN, M.S., KHAN, M.F., AKHTAR, N., KHAN, G.B., YASMIN, S., ALI, A., SAQLAIN, M., TAUSEEF, I. and SHAH, S.R., 2021. Prevalence of Hard Ticks in Cows and Buffaloes in District Malakand, Pakistan. Bioscience Research, vol. 18, no. 1, pp. 1461-1470.

AMSTRUP, S.C. and BEECHAM, J., 1976. Activity patterns of radiocollared black bears in Idaho. The Journal of Wildlife Management, vol. 40, no. 2, pp. 340-348. http://dx.doi.org/10.2307/3800435.

ESCOBAR, L.E., AWAN, M.N. and QIAO, H., 2015. Anthropogenic disturbance and habitat loss for the red-listed Asiatic black bear (Ursus thibetanus): using ecological niche modeling and nighttime light satellite imagery. Biological Conservation, vol. 191, pp. 400-407. http://dx.doi.org/10.1016/j.biocon.2015.06.040.

GARSHELIS, D.L. and STEINMETZ, R., 2016. Ursus thibetanus. In: INTERNATIONAL UNION FOR CONSERVATION OF NATURE AND NATURAL RESOURCES - IUCN, ed. The IUCN Red List of Threatened Species 2008. e. T22824A9391633. Cambridge: IUCN.

HAZUMI, T., 1993. Life of Asiatic black bear. Yamato Hakubutsukan, vol. 38, pp. 2-3.

HOWE, E.J., OBBARD, M.E., BLACK, R. and WALL, L.L., 2010. Do public complaints reflect trends in human-bear conflict? Ursus, vol. 21, no. 2, pp. 131-142. http://dx.doi.org/10.2192/09GR013.1.

KHAN, A., UMHANG, G., ULLAH, Z., BOUÉ, F., BASTID, V., ULLAH, I., MAHMOOD, S., AFZAL, M.S. and AHMED, H., 2021. Investigation of Echinococcus multilocularis in foxes and dogs in Pakistan by detection of copro-DNA. Parasitology Research, vol. 120, no. 2, pp. 731-737. http://dx.doi.org/10.1007/s00436-020-07001-x.

KUMAR, S. and VISWANATH, S., 2003. Observations on food habits of Asiatic black bear in Kedarnath Wildlife Sanctuary, India: preliminary evidence on their role in seed germination and dispersal. Ursus, vol. 14, no. 1, pp. 99-103.

LILEY, S.G. and WALKER, R.N., 2015. Extreme movement by an American black bear in New Mexico and Colorado. Ursus, vol. 26, no. 1, pp. 1-6. http://dx.doi.org/10.2192/URSUS-D-15-00006.1.

MCLELLAN, B. and REINER, D.C., 1994. A review of bear evolution. Bears: Their Biology and Management, vol. 8, pp. 85-96.

MCLELLAN, B.N., 2011. Implications of a high-energy and lowprotein diet on the body composition, fitness, and competitive abilities of black (Ursus americanus) and grizzly (Ursus arctos) bears. Canadian Journal of Zoology, vol. 89, no. 6, pp. 546-558. http://dx.doi.org/10.1139/z11-026.
MYERS, P.J., 2016. Spatial ecology and captive behavior of rehabilitated black bears in Utah. Logan: Utah State University.

PIRES, S.F. and MORETO, W.D., 2016. The illegal wildlife trade. Oxford: Oxford University Press.

RAHAT, M.A., HARIS, M., ULLAH, Z., AYAZ, S.G., NOUMAN, M., RASOOL, A. and ISRAR, M., 2020. Domestic animals' identification using PCR-RFLP analysis of cytochrome b gene. Advancements in Life Sciences, vol. 7, no. 3, pp. 113-116.

RIPPLE, W.J., ESTES, J.A., BESCHTA, R.L., WILMERS, C.C., RITCHIE, E.G., HEBBLEWHITE, M., BERGER, J., ELMHAGEN, B., LETNIC, M., NELSON, M.P., SCHMITZ, O.J., SMITH, D.W., WALLACH, A.D. and WIRSING, A.J., 2014. Status and ecological effects of the world's largest carnivores. Science, vol. 343, no. 6167, pp. 1241484. http://dx.doi.org/10.1126/science.1241484. PMid:24408439.

ROBERTS, T.J., 1997. The mammals of Pakistan. Karachi: Oxford University Press, $525 \mathrm{p}$.

SCHALLER, G.B., 1977. Mountain monarchs: wild sheep and goats of the Himalaya. Chicago: University of Chicago Press.

SERVHEEN, C., 1990. The status and conservation of the bears of the world. In: International Conference on Bear Research and Management; 1990; Victoria, BC. Victoria: International Association for Bear Research and Management, $32 \mathrm{p}$. Monograph Series. no. 2.

STEVENS, V., LOFTS, S. and HARCOMBE, A.P. (1988). Wildlife habitat handbooks for the southern interior ecoprovince: species notes for mammals. Wildlife Branch: Ministry of Environment, vol. 1.

ULLAH, Z., SAJID, M., IQBAL, Z., AKHTAR, N., KHAN, G.B., ALI, A., YASMIN, S., SAQLAIN, M., KHAN, M.A. and ARIF, M., 2021. Movement of asiatic black bear: sign survey evidence from Kaghan and Siran Valleys, Pakistan. Bioscience Research, vol. 18, no. 1, pp. 1433-1445.

ULLAH, Z., ULLAH, I., ULLAH, I., MAHMOOD, S. and IQBAL, Z., 2020. Poaching of Asiatic black bear: evidence from Siran and Kaghan valleys, Pakistan. Global Ecology and Conservation, vol. 24, pp. e01351. http://dx.doi.org/10.1016/j.gecco.2020.e01351.

WASEEM, M. and ALI, A. (2011). Asiatic Black bear in District Mansehra District Mansehra, Khyber Pakhtoonkhawa (Pakistan). WWF-Pakistan.

WOODS, C.A. and KALPATRICK, W.C., 1997. Biodiversity of small mammals in mountains of Pakistan. In S.A. MUFTI, C.A. WOODS and S.A. HASAN, eds. Biodiversity of Pakistan. Gainesville: Pakistan Museum of Natural History, Islamabad, Pakistan, and Florida Museum of Natural History, pp. 437-467.

YOUNG, B.F. and RUFF, R.L., 1982. Population dynamics and movements of black bears in east central Alberta. The Journal of Wildlife Management, vol. 46, no. 4, pp. 845-860. http:// dx.doi.org/10.2307/3808217. 